\title{
Simultaneous Analysis of 6-Mercaptopurine, 6-Methylmercaptopurine, and 6-Thioguanosine-5'-monophosphate in Dried Blood Spot Using Ultra Performance Liquid Chromatography Tandem Mass Spectrometry
}

\author{
Supandi ${ }^{1,2}$, Yahdiana Harahap ${ }^{2, *}$, Harmita $^{2}$, and Rizka Andalusia ${ }^{3}$ \\ ${ }^{1}$ Department of Pharmacy, Faculty of Pharmacy and Science UHAMKA, Jl. Delima II Klender Jakarta 13460, Indonesia \\ ${ }^{2}$ Faculty of Pharmacy, Universitas Indonesia, Jl. Kampus UI, Depok 16424, Indonesia \\ ${ }^{3}$ Department of Research and Development, Dharmais Cancer Hospital, Jl. S. Parman Kav. 84-86 Slipi Jakarta 11420, Indonesia
}

Received December 8, 2017; Accepted February 5, 2018

\begin{abstract}
6-Mercaptopurine is a chemotherapeutic agent of the antimetabolite class. This study aims to analyze simultaneous validation of 6-mercaptopurine (6-MP), 6-methylmercaptopurine (6-MMP), and 6-thioguanosine-5'monophosphate (6-TGMP) in dried blood spot (DBS) using ultra performance liquid chromatography-tandem mass spectrometry (UPLC-MS/MS). An accurate volume of $60 \mu \mathrm{L}$ blood was spotted onto DBS-CAMAG paper and then extracted using methanol $90 \%(\mathrm{~V} / \mathrm{V}$ ) containing an internal standard of 5-fluorouracil (5-FU). Separation was performed using a Waters Acquity UPLC BEH AMIDA column $1.7 \mu \mathrm{m}(2.1 \times 100 \mathrm{~mm})$ with a mobile phase mixture of $0.2 \%(\mathrm{~V} / \mathrm{V})$ formic acid in water-0.1\% ( $/ \mathrm{V})$ formic acid in acetonitrile-methanol with gradient elution and flow rate of $0.2 \mathrm{~mL} / \mathrm{min}$. Mass detection was done using Waters Xevo TQD with positive electrospray ionization (ESI) for 6-MP, 6-MMP, 6-TGMP and negative ESI for 5-FU, in multiple reaction monitoring mode. Detection rates of 6-MP, 6-MMP, 6-TGMP and 5-FU were $\mathrm{m} / \mathrm{z} 153.09>119.09 ; 167.17>126.03 ; 380.16>168.00) ; 129.09>42.05$, respectively. This method is linear across the range of 25.5-1020 $\mathrm{ng} / \mathrm{mL}$ for 6-MP, 6-MMP and 6-TGMP. This method is valid for the in vitro simultaneous analysis of 6-MP, 6-MMP and 6-TGMP in DBS, based on European Medicine Agency guidelines.
\end{abstract}

Keywords: 6-mercaptopurine; dried blood spot; simultaneous analysis; method validation

\section{ABSTRAK}

6-Merkaptopurin merupakan agen kemoterapi yang termasuk golongan antimetabolit analog purin. Penelitian ini bertujuan untuk menganalisis secara simultan 6-merkaptopurin (6-MP),6-metilmerkaptopurin (6-MMP), dan 6tioguanosin-5'-monofosfat (6-TGMP) pada sampel darah kering dengan menggunakan kromatografi cair kinerja ultra tinggi-tandem spektrometri massa (KCKUT-SM/SM). Sebanyak $60 \mu \mathrm{L}$ darah utuh ditotolkan pada kertas DBSCAMAG, ditambahkan baku dalam 5-fluorourasil (5-FU) kemudian diekstraksi menggunakan metanol 90\% ( $\mathrm{V} / \mathrm{V})$. Analisis dilakukan dengan kolom Waters Acquity UPLC BEH AMIDA 1,7 $\mu \mathrm{m}(2,1 \times 100 \mathrm{~mm})$ dengan fase gerak campuran $0,2 \%(\mathrm{~V} / \mathrm{V})$ asam format dalam air-0,1\% ( $/ \mathrm{V})$ asam format dalam asetonitril-metanol, elusi secara gradien dan laju alir 0,2 $\mathrm{mL} /$ menit. Deteksi massa dilakukan menggunakan Waters Xevo TQD dengan ionisasi electrospray (ESI) positif untuk 6-MP, 6-MMP, 6-TGMP dan ESI negatif untuk 5-FU dengan mode multiple reaction monitoring. Deteksi 6-MP, 6-MMP, 6-TGMP, 5-FU masing-masing adalah $\mathrm{m} / \mathrm{z} 153,09>119,09 ; 167,17>126,03 ; 380,16>$ 168,00); 129,09 > 42,05. Metode ini linier dengan kisaran 25,5-1020 ng/mL untuk $6 \mathrm{MP}$, 6-MMP, dan 6-TGMP. Metode ini valid untuk analisis 6-MP, 6-MMP, dan 6-TGMP pada sampel darah kering secara simultan secara in vitro sesuai dengan pedoman European Medicines Agency.

Kata Kunci: 6-merkaptopurin; sampel darah kering; analisis simultan; validasi metode

\section{INTRODUCTION}

The chemotherapeutic agent of 6-mercaptopurine (6-MP) is used in most treatment protocols for acute lymphoblastic leukemia (ALL) [1-2]. 6-MP has three major metabolic pathways: the first uses the enzyme hypoxanthine-guanine phosphoribosyltransferase (HGPRT) to form its active metabolite, 6-thioguanine nucleotide (6-TGN). The second pathway uses the enzyme thiopurine methyltransferase (TPMT) to form 6methylmercaptopurine (6-MMP), and the third pathway uses the enzyme xanthine dehydrogenase to form 6thiouric acid [3-5]. In chemotherapy, the focus of clinical research is slowly shifting from improving

* Corresponding author. Tel : +62-818222192

DOI: $10.22146 /$ ijc.31116

Email address : yahdiana14@gmail.com

Supandi et al. 
survival rates to decreasing chemotherapy-related adverse effects [6-7]. 6-MP produces a range of possible adverse drug reactions and a narrow therapeutic index; hence, the therapeutic index for each individual needs to be monitored [8]. 6-MP drug monitoring is usually performed by venipuncture [3,6,9-10]. Venous blood sampling has the disadvantages of requiring large blood samples, and as an invasive process, requiring medical personnel to perform venipuncture [11]. DBS analysis, which is a bio-sampling method developed recently for therapeutic drug monitoring, overcomes these problems. The main benefits of DBS analysis are the opportunity for long storage at room temperature, simple transportation in envelopes and minimally invasive blood sampling without direct sample processing. Due to this low processing burden, DBS analysis methods are particularly suitable for the elderly, children and infants for whom venipuncture is problematic [12-15].

This research aims to develop valid analytical methods for 6-MP, 6-MMP, and 6-TGMP simultaneously in DBS samples using UPLC-MS/MS with 5-fluorouracil as the internal standard. Sample preparation and extraction uses a mixture of aqueous, acetonitrile and methanol processes. Optimization and validation method meet the requirements of the European Medicine Agency. The new contribution of this research is to describe a simple, rapid, sensitive and selective method for simultaneous analysis of 6-mercaptopurine and its metabolites in DBS samples using UPLC-MS/MS. This method is still under development in the laboratory, and in future is expected to be applied in 6-MP therapeutic drug monitoring of childhood patients with ALL.

\section{EXPERIMENTAL SECTION}

\section{Materials}

Acetonitrile HPLC grade (Merck), formic acid (Merck), methanol HPLC grade (Merck), 6mercaptopurine (Sigma-Aldrich), 6-methylmercaptopurine (Sigma-Aldrich), 6-thioguanosine-5'-monophosphate (Jena Bioscience) were used in this research. All water used was HPLC grade and prepared using a Millipore Direct-QTM 5 water system (Millipore, Watford, UK). Whole blood was obtained from the Indonesian Red Cross.

\section{Instrumentation}

The instruments used in this study were: quaternary solvent manager (Acquity UPLC H-Class), sample manager (Acquity UPLC), mass analyzer triple quadrupole (Xevo TQD), nitrogen generator compressor (PEAK Scientific), UPLC bridged ethylene hybrid AMIDA column $1.7 \mu \mathrm{m}(2.1 \mathrm{~mm} \times 100 \mathrm{~mm})$, digital balance
(AND), ultrasonic (Elmasonic S40H), deep freezer -20 ${ }^{\circ} \mathrm{C}$ (Modena), TurboVap evaporator (Califer), vortex (Maxi Mix II), micropipettes (Soccorex) and millipore $0.22 \mu \mathrm{m}$ (Chrom Tech).

\section{Procedure}

\section{Stock solutions, standards and quality controls}

Standard and stock solutions of $1 \mathrm{mg} / \mathrm{mL}$ of dissolved 6-MP, 6-MMP, 6-TGMP and 5-FU were freshly prepared, and the stock solutions were stored at $-20{ }^{\circ} \mathrm{C}$. All working standard solutions were freshly prepared from the stock before each analytic run.

Calibrating solutions were freshly prepared at scalar concentrations by diluting stock solutions in acetonitrile $50 \%(\mathrm{v} / \mathrm{v})$ for $6-\mathrm{MP}, 6-\mathrm{MMP}$ and 5-FU. The stock solution for 6-TGMP was diluted in water. These solutions would later be diluted in whole blood to produce the desired concentrations.

\section{DBS sample preparation}

Whole blood was obtained from the Indonesian Red Cross and stored at $-40{ }^{\circ} \mathrm{C}$ until required. An aliquot of $60 \mu \mathrm{L}$ blood standards of analytes was pipetted and spotted onto CAMAG DBS paper and dried for a minimum of $3 \mathrm{~h}$ at room temperature. The DBS samples were then cut and put into tubes. Extraction solution consisting of $1 \mathrm{~mL}$ methanol $90 \%$ $(\mathrm{v} / \mathrm{v})$ with the addition of $100 \mu \mathrm{L}$ of internal standard of 5 -FU solution was added to the tubes. Tubes were sonicated for $25 \mathrm{~min}$ at $50{ }^{\circ} \mathrm{C}$. The supernatant was then transferred into test tubes and evaporated with nitrogen for $25 \mathrm{~min}$ at $40{ }^{\circ} \mathrm{C}$. It was then reconstituted in $100 \mu \mathrm{L}$ acetonitrile $10 \%(\mathrm{v} / \mathrm{v})$, then vortexed and sonicated for $10 \mathrm{sec}$. After being centrifuged at 3000 rpm for $10 \mathrm{~min}$ with $10 \mu \mathrm{L}$ of the aliquot, it was injected into the chromatographic system.

\section{Method validation}

Assay validation was performed based on the EMA guidelines for validation of bioanalytical assay [15-16]. In addition, experiments were conducted to determine the effects of DBS analysis on the selectivity, carry-over, lower limit of quantitation, calibration curve, accuracy, precision, dilution integrity, matrix effect and stability of the method.

\section{RESULT AND DISCUSSION}

\section{Method Optimization}

The mobile phases used were $0.2 \%(\mathrm{v} / \mathrm{v})$ formic acid in water $-0.1 \%(\mathrm{v} / \mathrm{v})$ formic acid in acetonitrilemethanol. The flow rate was $0.2 \mathrm{~mL} / \mathrm{min}$ using gradient elution conditions and injection volume of $5 \mu \mathrm{L}$. The 
runtime was approximately $5 \mathrm{~min}$. The mass selective detector was operated in electrospray ionization positive mode for analytes, and negative mode for the internal standard (IS). Mass spectrometric (MS) detection was performed using Waters Xevo TQD Triple Quadruple and multiple reaction monitoring was employed with mass resolutions of wide for MS1 and widest for MS2. High purity nitrogen was used as source and collision gas. Capillary voltage was set to $3.5 \mathrm{kV}, 450{ }^{\circ} \mathrm{C}$ as the desolvation temperature, $700 \mathrm{~L} / \mathrm{h}$ as desolvation gas flow and $0.025 \mathrm{msec}$ as dwell time.

The UPLC-MS/MS conditions to determine analytes and IS are shown in Table 1. Two product ions from one precursor ion were set for multiple reaction monitoring (MRM) mode. Typical chromatograms of the analytes $(1.0 \mu \mathrm{g} / \mathrm{mL})$ are shown in Fig. 1 .

Even when the MS/MS parameters are optimized for these product ions, their abundance remains low, as the majority of the precursor ions remain intact. Increasing the collisions further does not increase the abundance of these two product ions. However, the results show the formation of numerous lower-mass and low-abundance product ions [17-18].

\section{Determination of Extraction Solvent}

Many smaller molecule methods use organic solvents to extract the analyte from the DBS sample. Organic solvents are generally used as extraction solutions because, in addition to being able to attract the analytes, organic solvents can precipitate blood proteins [19]. The addition of an organic solution to a solution of a protein in water can lower the dielectric constant of the solvent/water, thereby increasing the pull between the charged molecules and facilitating the electrostatic interaction of protein. In addition, organic solvents can replace several water molecules in the hydrophobic area of the protein surface and associate with proteins by decreasing the water concentration in the solution; this process causes the protein solubility to

Table 1. MRM parameters for the analysis of 6-MP, 6-MMP, 6-TGMP and 5-FU

\begin{tabular}{lcccccc}
\hline Analyte & $\begin{array}{c}\text { Parent ion } \\
(\mathrm{m} / \mathrm{z})\end{array}$ & $\begin{array}{c}\text { Product ion } \\
(\mathrm{m} / \mathrm{z})\end{array}$ & $\begin{array}{c}\text { Cone } \\
\text { voltage }\end{array}$ & $\begin{array}{c}\text { Collision } \\
\text { energy }\end{array}$ & $\begin{array}{c}\text { Ion } \\
\text { mode }\end{array}$ & Abundance \\
\hline 6-MP & 153.10 & 126.00 & 44 & 20 & $\mathrm{ESI}+$ & $4.41 \mathrm{e}^{\wedge} 4$ \\
& & 119.09 & 52 & 23 & $\mathrm{ESI}+$ & $4.41 \mathrm{e}^{\wedge} 6$ \\
6-MMP & 167.05 & 152.03 & 38 & 22 & $\mathrm{ESI}+$ & $2.96 \mathrm{e}^{\wedge} 5$ \\
& & 126.03 & 38 & 18 & $\mathrm{ESI}+$ & $1.19 \mathrm{e}^{\wedge} 6$ \\
6-TGMP & \multirow{2}{*}{380.16} & 168.00 & 44 & 18 & $\mathrm{ESI}+$ & $4.41 \mathrm{e}^{\wedge} 6$ \\
& & 151.10 & 32 & 50 & $\mathrm{ESI}+$ & $2.11 \mathrm{e}^{\wedge} 6$ \\
5-FU & \multirow{2}{*}{129.15} & 86.17 & 28 & 24 & $\mathrm{ESI}-$ & $1.21 \mathrm{e}^{\wedge} 3$ \\
& & 42.05 & 28 & 14 & $\mathrm{ESI}-$ & $9.48 \mathrm{e}^{\wedge} 4$ \\
\hline
\end{tabular}

MRM: multiple reaction monitoring; 6-MP: 6-mercaptopurine; 6-MMP: 6-methylmercaptopurine 6-TGMP: 6-thioguanosine-5'-monophosphate, 5-FU: 5-fluorouracil
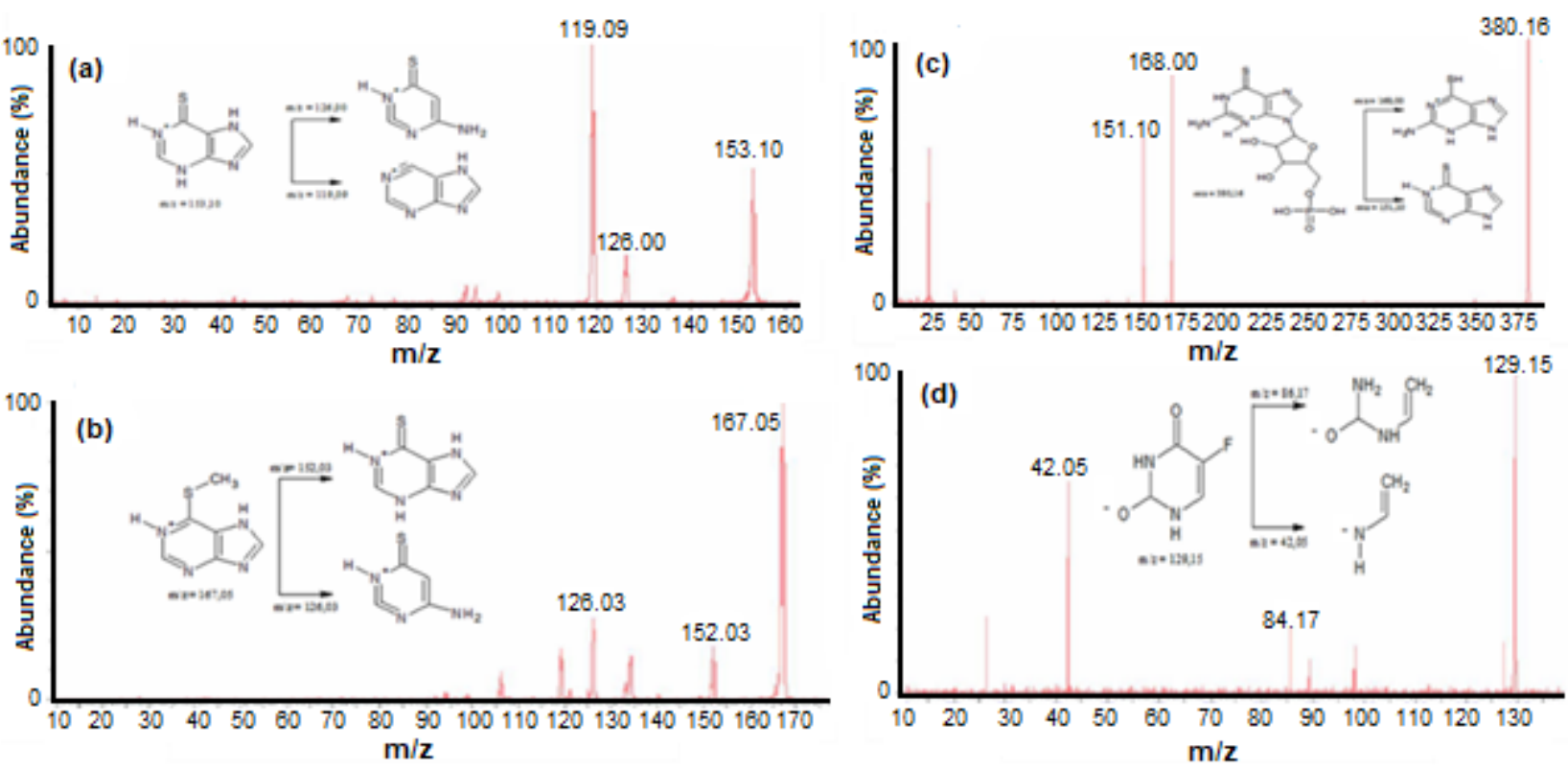

Fig 1. Mass spectra and ion fragmentation: (a) 6-mercaptopurine, (b) 6-methylmercaptopurine, (c) 6-thioguanosine5'-monophosphate and (d) 5-fluorouracil 
Table 2. Extracts from DBS samples using various solvents and reconstitution

\begin{tabular}{|c|c|c|c|c|c|}
\hline \multirow[t]{2}{*}{ Solvent } & \multirow{2}{*}{$\begin{array}{l}\text { Reconstitution } \\
(100 \mu \mathrm{L})\end{array}$} & \multicolumn{4}{|c|}{ Area } \\
\hline & & 6-MP & 6-MMP & 6-TGMP & $5-F U$ \\
\hline Methanol 100\% & Methanol 10\% & 13763 & 82175 & 423 & 7360 \\
\hline$(4 \mathrm{~mL})$ & Acetonitrile $10 \%$ & 89747 & 26377 & 246 & 3407 \\
\hline Methanol $90 \%$ & Methanol 10\% & 80125 & 219314 & 3646 & 5970 \\
\hline$(1 \mathrm{~mL})$ & Acetonitrile $10 \%$ & 87707 & 258755 & 3472 & 6103 \\
\hline Acetonitrile $90 \%$ & Methanol 10\% & 11488 & 337009 & 419 & 15121 \\
\hline$(1 \mathrm{~mL})$ & Acetonitrile $10 \%$ & 90506 & 239771 & 385 & 13495 \\
\hline
\end{tabular}
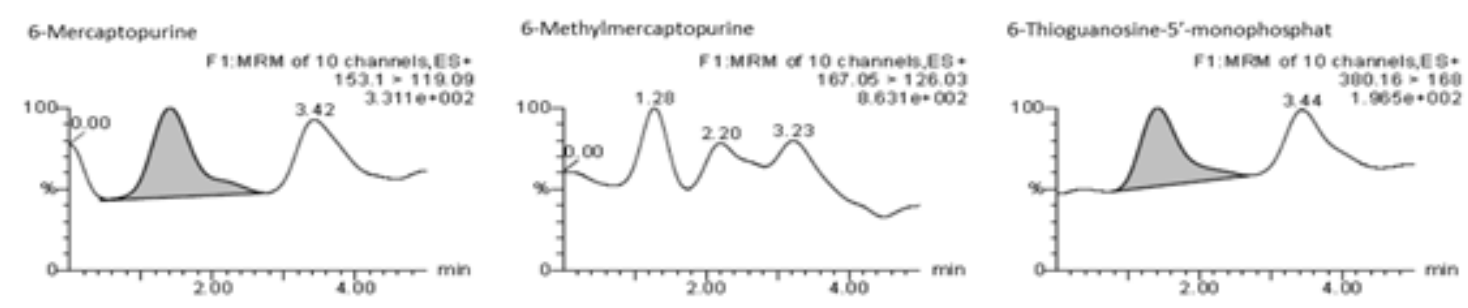

(a)
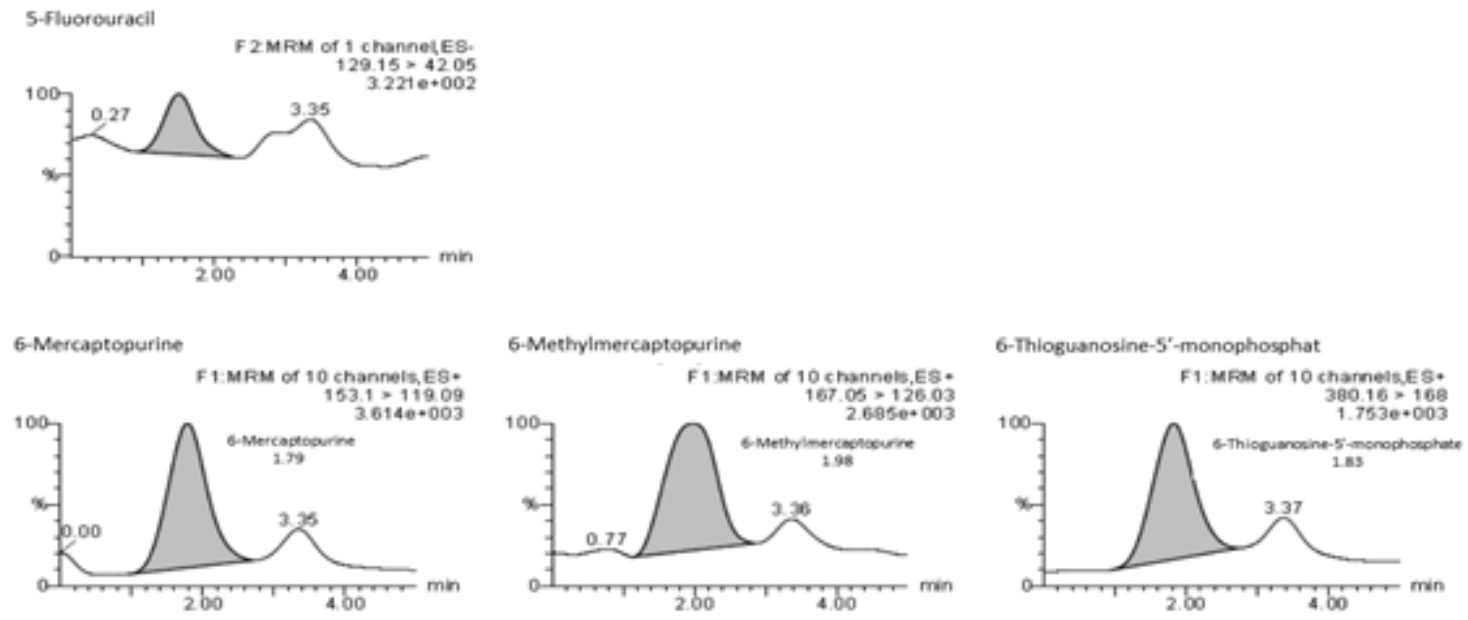

(b)

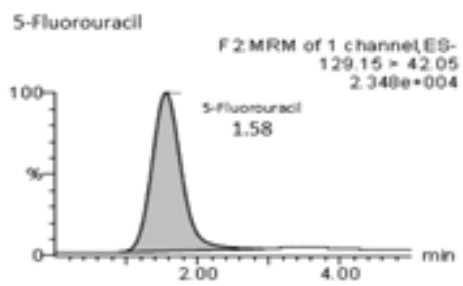

Fig 2. Chromatograms of blank matrix extracted without internal standard (a) and LLOQ sample extracted with internal standard (b)

decrease and allows for precipitation [16].

Three solvents, methanol $100 \%(\mathrm{v} / \mathrm{v})$, methanol $90 \%(\mathrm{v} / \mathrm{v})$ and acetonitrile $90 \%(\mathrm{v} / \mathrm{v})$, were compared by sonication for $25 \mathrm{~min}$ and reconstituting in methanol $10 \%$ $(\mathrm{v} / \mathrm{v})$ and acetonitrile $10 \%(\mathrm{v} / \mathrm{v})$. The mean values of peak areas acquired through UPLC-MS/MS were used for comparison of the three extraction solvent efficiencies, as shown in Table 2. Generally, acetonitrile $90 \%(\mathrm{v} / \mathrm{v})$ has been used as the extraction solvent for 6 MP, 6-MMP and 5-FU analysis with UPLC-MS/MS because it shows better area than methanol. Methanol $90 \%(\mathrm{v} / \mathrm{v})$ has a better extraction results for 6 -TGMP. All the target compounds were extracted effectively by methanol $90 \%(\mathrm{v} / \mathrm{v})$, and the differences were not large. Methanol $90 \%(\mathrm{v} / \mathrm{v})$ showed the best extraction results for most of the target compounds and this solvent was selected for 6-MP, metabolites and IS analysis of blood, based on the experimental results.

\section{Bioanalytical Validation Assay}

\section{Selectivity and carry-over}

Interference from endogenous compounds was investigated by analyzing six different sources of the 
appropriate blank matrix. Blank whole blood was spotted onto DBS analysis paper and prepared using the preparation method detailed above. The absence of interfering components is considered acceptable where

Table 3. Accuracy and precision data of the assay

\begin{tabular}{|c|c|c|c|c|c|c|}
\hline \multirow{2}{*}{$\begin{array}{l}\text { Nominal } \\
\text { conc. } \\
(\mathrm{ng} / \mathrm{mL})\end{array}$} & \multicolumn{3}{|c|}{ Within-run $(n=5)$} & \multicolumn{3}{|c|}{ Between-run $(n=5)$} \\
\hline & $\begin{array}{c}\text { Measured } \\
\text { conc. }(\mathrm{ng} / \mathrm{mL}) \\
{[\text { mean } \pm \mathrm{SD}]} \\
\end{array}$ & $\begin{array}{c}\text { Bias } \\
\text { (\% diff) }\end{array}$ & $\begin{array}{c}\text { Precision } \\
(\% \text { CV })\end{array}$ & $\begin{array}{c}\text { Measured } \\
\text { conc. }(\mathrm{ng} / \mathrm{mL}) \\
{[\text { mean } \pm \mathrm{SD}]}\end{array}$ & $\begin{array}{c}\text { Bias } \\
(\% \text { diff })\end{array}$ & $\begin{array}{l}\text { Precision } \\
(\% \text { CV })\end{array}$ \\
\hline \multicolumn{7}{|l|}{ 6-MP } \\
\hline 25.50 & $28.74 \pm 2.36$ & $-0.40-19.33$ & 8.23 & $29.22 \pm 1.59$ & $4.46-19.94$ & 5.43 \\
\hline 75.00 & $78.33 \pm 6.47$ & $-1.02-13.65$ & 6.61 & $78.45 \pm 1.33$ & $9.66-13.12$ & 1.30 \\
\hline 510.00 & $575.74 \pm 14.40$ & $7.92-14.92$ & 2.5 & $530.57 \pm 33.47$ & $-4.26-10.96$ & 6.31 \\
\hline 918.00 & $943.80 \pm 65.35$ & $-8.01-10.50$ & 6.92 & $827.73 \pm 51.14$ & $-14.76-1.315$ & 6.18 \\
\hline \multicolumn{7}{|l|}{ 6-MMP } \\
\hline 25.50 & $28.19 \pm 2.01$ & $-2.23-16.69$ & 7.11 & $29.32 \pm 0.72$ & $11.94-18.54$ & 2.44 \\
\hline 75.00 & $82.72 \pm 0.48$ & $13.15-14.44$ & 0.46 & $81.23 \pm 1.93$ & $7.93-12.18$ & 1.91 \\
\hline 510.00 & $541.98 \pm 48.75$ & $-7.02-13.49$ & 8.99 & $527.36 \pm 55.59$ & $-10.3-14.16$ & 10.54 \\
\hline 918.00 & $1025.26 \pm 43.13$ & $3.40-15.00$ & 4.21 & $947.51 \pm 37.35$ & $-1.21-9.84$ & 3.94 \\
\hline \multicolumn{7}{|l|}{ 6-TGMP } \\
\hline 51.00 & $58.75 \pm 0.91$ & $12.48-17.19$ & 1.54 & $58.34 \pm 0.96$ & $11.55-16.69$ & 1.64 \\
\hline 150.00 & $161.11 \pm 6.19$ & $5.37-14.42$ & 3.13 & $153.84 \pm 7.65$ & $4.41-14.56$ & 3.83 \\
\hline 510.00 & $464.83 \pm 22.58$ & $-12.61-1.56$ & 4.86 & $508.00 \pm 39.59$ & $-9.87-9.14$ & 7.79 \\
\hline 918.00 & $800.57 \pm 6.40$ & $-13.33-11.6$ & 0.80 & $956.78 \pm 44.58$ & $-1.88-8.36$ & 4.66 \\
\hline
\end{tabular}

Table 4. Matrix effect: analytes and internal standard

\begin{tabular}{|c|c|c|c|c|c|}
\hline \multirow{2}{*}{$\begin{array}{c}\text { Concentration } \\
(\mathrm{ng} / \mathrm{mL})\end{array}$} & \multirow[t]{2}{*}{ Blood lot } & \multicolumn{4}{|c|}{ ME (\%) } \\
\hline & & 6-MP & 6-MMP & 6-TGMP & $5-\mathrm{FU}$ \\
\hline \multirow{12}{*}{$\begin{array}{l}\text { QCL } \\
6-\mathrm{MP} \text { and 6-MMP }= \\
75.00 \\
6-\mathrm{TGMP}=150.00\end{array}$} & \multirow[t]{2}{*}{ A } & 69.57 & 83.91 & 90.24 & 82.00 \\
\hline & & 69.85 & 81.94 & 87.57 & 78.15 \\
\hline & \multirow[t]{2}{*}{ B } & 83.43 & 79.19 & 97.20 & 80.65 \\
\hline & & 79.76 & 85.51 & 92.54 & 81.80 \\
\hline & \multirow[t]{2}{*}{ C } & 83.46 & 83.83 & 85.77 & 83.15 \\
\hline & & 79.97 & 77.76 & 78.06 & 81.47 \\
\hline & \multirow[t]{2}{*}{ D } & 78.61 & 97.67 & 87.57 & 82.64 \\
\hline & & 73.41 & 93.87 & 86.26 & 80.82 \\
\hline & \multirow[t]{2}{*}{$\mathrm{E}$} & 80.67 & 96.58 & 75.39 & 80.67 \\
\hline & & 100.10 & 96.73 & 74.46 & 79.80 \\
\hline & \multirow[t]{2}{*}{$\mathrm{F}$} & 90.09 & 83.14 & 88.69 & 82.72 \\
\hline & & 80.39 & 91.57 & 88.44 & 82.43 \\
\hline \multirow{12}{*}{$\mathrm{QCH}=918.00$} & \multirow[t]{2}{*}{ A } & 76.66 & 91.31 & 89.48 & 82.10 \\
\hline & & 70.70 & 83.31 & 89.71 & 78.71 \\
\hline & \multirow[t]{2}{*}{ B } & 70.64 & 80.39 & 98.69 & 80.63 \\
\hline & & 75.02 & 83.65 & 89.11 & 83.05 \\
\hline & \multirow[t]{2}{*}{ C } & 66.94 & 88.51 & 82.66 & 80.27 \\
\hline & & 72.29 & 70.06 & 87.84 & 78.25 \\
\hline & \multirow[t]{2}{*}{ D } & 63.58 & 80.58 & 73.52 & 78.89 \\
\hline & & 81.40 & 82.33 & 77.47 & 79.66 \\
\hline & \multirow[t]{2}{*}{$\mathrm{E}$} & 67.13 & 73.46 & 73.89 & 81.26 \\
\hline & & 73.50 & 92.66 & 73.74 & 83.49 \\
\hline & \multirow[t]{2}{*}{$\mathrm{F}$} & 85.24 & 85.18 & 89.89 & 81.50 \\
\hline & & 81.60 & 83.12 & 86.35 & 76.06 \\
\hline \multirow{2}{*}{ Measured } & QCL & 80.78 & 87.64 & 86.01 & 81.35 \\
\hline & $\mathrm{QCH}$ & 73.73 & 82.88 & 84.36 & 80.32 \\
\hline \multirow{2}{*}{ SD } & QCL & 8.42 & 7.21 & 6.83 & 1.43 \\
\hline & $\mathrm{QCH}$ & 6.59 & 6.53 & 8.09 & 2.14 \\
\hline \multirow{2}{*}{$\% \mathrm{CV}$} & QCL & 10.42 & 8.23 & 7.94 & 1.76 \\
\hline & $\mathrm{QCH}$ & 8.93 & 7.88 & 9.59 & 2.67 \\
\hline
\end{tabular}

ME: matrix effect; QCL: quality control low; QCH: quality control high: 6-MP: 6-mercaptopurine; 6-MMP:6methylmercaptopurine; 6-TGMP: 6-thioguanosine-5'-monophosphate 
the response is less than $20 \%$ of the lower limit of quantification (LLOQ) for the analyte. Interference may be caused by substances with equal mass, and with the same retention times as the analytes. The optimized methods were selective for 6-MP, 6-MMP, 6-TGMP and 5 -FU because the response of blank matrix is less than $20 \%$ of LLOQ analyte [15]. Corresponding chromatograms are presented in Fig. 2.

Carry-over was assessed by injecting blank DBS samples following a high-concentration sample of calibration standard at the upper limit of quantification. Carry-over in the blank should not be greater than $20 \%$ of the LLOQ. Carry-over was avoided, and the analyte signal at LLOQ concentration substantially exceeded the minimal limit of the validation requirements. The analytical concentration of $1020 \mathrm{ng} / \mathrm{mL}$ gave a 6 -MP carry-over yield of $4.30-7.46 \%, 6-\mathrm{MMP}$ of $0-5.17 \%$ and 6 -TGMP of $5.33-13.46 \%$.

\section{Linearity}

Calibration curves were measured using a blank, a zero and samples at five concentration levels and prepared at scalar concentrations. The mean regression coefficient was calculated. Linearity was achieved for a range of 25.5 to $1020 \mathrm{ng} / \mathrm{mL}$ for 6-MP and 6-MMP, and a range of 51 to $1020 \mathrm{ng} / \mathrm{mL}$ for 6-TGMP. The linear regression of calibration curve resulted consistently in a correlation coefficient of $r^{2}>0.9940,0.9878$ and 0.9882 for 6-MP, 6-MMP and 6-TGMP, respectively. The linear model test based on ANOVA showed no significant lack of fit. The CV and biases at each calibration level were all less than $15 \%$.

\section{Accuracy and precision}

Accuracy and precision were determined at four concentrations stated as LLOQ quality control low $(\mathrm{QCL})$, quality control medium (QCM) and quality control high (QCH). Accuracy was determined by differences between theoretical value and calculated value and expressed as the bias (\% diff) while precision was expressed as the coefficient of variation (\% CV). These parameters should be $\leq \pm 15 \%$ for the quality control samples and should be $\leq 20 \%$ for LLOQ. Within-run and between-run precision and accuracy data were always less than $15 \%$ for the QC samples and less than $20 \%$ for the LLOQ (Table 3).

\section{Matrix effect}

Matrix effect (ME) was assessed using at least six blank matrices from individual donors. Matrix effects were determined in triplicate $(n=3)$ by the comparison of two values at low and high concentrations. The area value of neat standard analyzed with LC-MS/MS was directly expressed as A. Standard spiked into the extraction solvent after extraction of blood spotted on a DBS card was expressed as B. The matrix effect (\%) was calculated as $\mathrm{B} / \mathrm{A} \times 100 \%$. The matrix effect values of 6-MP, 6-MMP, 6-TGMP and IS were observed at low levels as $80.78,87.64,86.01$ and $81.35 \%$, respectively. At the high levels, it showed the lowest matrix effect value of $73.73,82.88,84.36$, and $80.32 \%$, respectively. The results indicate that ion suppression affected the ionization in LC-MS/MS. Ion suppression or enhancement within $10 \%$ indicates no interference affecting the ionization of the analyte [20]. In this analysis with DBS samples, most target compounds showed ion suppression values above $10 \%$, indicating that DBS card components had considerable effects on the ionization of analytes (Table 4).

\section{Stability}

Stability of analytes in DBS samples was assessed in terms of short-term stability of up to $24 \mathrm{~h}$ at room temperature and long-term stability of up to 15 days. Stock solution stability was evaluated by comparing the peak areas obtained from direct injection of a diluted solution prepared from the stock stored at $-20{ }^{\circ} \mathrm{C}$ for 16 days with other peak areas obtained from direct injection obtained from freshly prepared stock. The stock solution did not show degradation after 16 days of storage at $-20{ }^{\circ} \mathrm{C}$ from freshly prepared stock solution. To determine long-term stability, the DBS samples should be stored in sealed plastic bags containing silica gel desiccants for 15 days, then determined by analyzing DBS samples

Table 5. Long-term stability of 6-MP, 6-MMP and 6-TGMP

\begin{tabular}{|c|c|c|c|c|c|c|c|c|c|c|c|c|}
\hline \multirow{3}{*}{$\begin{array}{l}\text { Time } \\
\text { (days) }\end{array}$} & \multicolumn{4}{|c|}{ 6-MP } & \multicolumn{4}{|c|}{ 6-MMP } & \multicolumn{4}{|c|}{ 6-TGMP } \\
\hline & \multicolumn{2}{|c|}{ QCL } & \multicolumn{2}{|c|}{$\mathrm{QCH}$} & \multicolumn{2}{|c|}{ QCL } & \multicolumn{2}{|c|}{$\mathrm{QCH}$} & \multicolumn{2}{|c|}{ QCL } & \multicolumn{2}{|c|}{$\mathrm{QCH}$} \\
\hline & $\% \mathrm{CV}$ & \%diff & $\% \mathrm{CV}$ & \%diff & $\% \mathrm{CV}$ & \%diff & $\% \mathrm{CV}$ & \%diff & $\% C V$ & \%diff & $\% \mathrm{CV}$ & \%diff \\
\hline & & -1.39 & & -7.59 & & 11.69 & & 2.50 & & 4.03 & & -3.13 \\
\hline 1 & 7.95 & 12.82 & 8.93 & $\overline{8} . \overline{81}$ & 1.27 & $\begin{array}{r}- \\
14.50\end{array}$ & 5.42 & $\begin{array}{c}- \\
13.97\end{array}$ & 1.75 & $\begin{array}{c}- \\
7.69\end{array}$ & 5.58 & $\begin{array}{l}- \\
8.19\end{array}$ \\
\hline 15 & 1.67 & $\begin{array}{c}- \\
1.44\end{array}$ & 1.86 & $-\overline{6.66}$ & 0.73 & $\begin{array}{c}- \\
14.08\end{array}$ & 4.55 & $\begin{array}{c}- \\
6.39\end{array}$ & 7.06 & $\begin{array}{c}- \\
13.97\end{array}$ & 4.60 & $\begin{array}{c}- \\
13.80\end{array}$ \\
\hline
\end{tabular}

QCL: quality control low; QCH: quality control high: 6-MP: 6-mercaptopurine; 6-MMP:6-methylmercaptopurine; 6-TGMP: 6-thioguanosine5'-monophosphate 
containing the analytes at two concentrations $(\mathrm{QCL}$ and $\mathrm{QCH}$; each concentration; $\mathrm{n}=3$ ). Stability testing revealed that 6-MP, 6-MMP and 6-TGMP spotted on DBS cards were stable for at least 15 days if stored at room temperature (as shown in Table 5).

Our method has the advantages of fast run time (5 min) and simple sample preparation with protein precipitation [21]. The analytical method was valid, and all the parameters fulfilled the acceptance criteria of the EMA Bioanalytical Method Validation Guidelines. Further studies need to be carried out, specifically the application of this method to therapeutic drug monitoring of ALL patients receiving 6-MP as their therapy.

\section{CONCLUSION}

The analytical method was valid for the in vitro simultaneous analysis of 6-MP, 6-MMP and 6-TGMP in DBS samples. All the parameters fulfilled the acceptance criteria of the EMA Bioanalytical Method Validation Guidelines. The DBS preparation procedure is simple, involving protein precipitation followed by analyte reconstitution.

\section{REFERENCES}

[1] Hunger, S.P., and Mullighan, C.G., 2015, Acute lymphoblastic leukaemia in children, $N$. Engl. J. Med., 375 (16), 1541-1552.

[2] Stork, L.C., Matloub, Y., Broxson, E., La, M., Yanofsky, R., Sather, H., Hutchinson, R., Heerema, N.A., Sorrell, A.D., Masterson, M., Bleyer, A., and Gaynon, P.S., 2010, Oral 6-mercaptopurine versus oral 6-thioguanine and veno-occlusive disease in children with standard-risk acute lymphoblastic leukaemia: Report of the Children's Oncology Group CCG-1952 clinical trial, Blood, 115 (14), 2740-2748.

[3] Beaumais, T.A., Fakhoury, M., Medard, Y., Azougagh, S., Zhang, D., Yakouben, K., and JacqzAigrain, E., 2011, Determinants of mercaptopurine toxicity in paediatric acute lymphoblastic leukaemia maintenance therapy, Br. J. Clin. Pharmacol., 71 (4), 575-584.

[4] Dervieux, T., Meyer, G., Barham, R., Matsutani, M., Barry, M., Boulieu, R., Neri, B., and Seidmans, E., 2005, Liquid chromatography-tandem mass spectrometry analysis of erythrocyte thiopurine nucleotides and effect of thiopurine methyltransferase gene variants on these metabolites in patients receiving azathioprine/6mercaptopurine therapy, Clin. Chem., 51 (11), 2074-2084.

[5] Dipiro, J.T., Talbert, R.L., Yee, G.C., Matzke, G.R., Wells, B.G., and Posey, L.M., 2008,
Pharmacotherapy A Pathophysiologic Approach, $7^{\text {th }}$ Ed., McGraw-Hill, New York, 733-735.

[6] Al-Ghobashy, M.A., Hassan, S.A., Abdelaziz, D.H., Elhosseiny, N.M,, Sabry, N.A., Attia, A.S., and ElSayed, M.H., 2016, Development and validation of LC-MS/MS assay for the simultaneous determination of methotrexate, 6-mercaptopurine and its active metabolite 6-thioguanine in plasma of children with acute lymphoblastic leukaemia: Correlation with genetic polymorphism, J. Chromatogr. B, 1038, 88-94.

[7] Schmiegelow, K., and Bretton-Meyer, U., 2001, 6Mercaptopurine dosage and pharmacokinetics influence the degree of bone marrow toxicity following high-dose methotrexate in children with acute lymphoblastic leukaemia, Leukemia, 15 (1), 74-79.

[8] Kirchherr, H., Shipkova, M., and von Ahsen, N., 2013, Improved method for therapeutic drug monitoring of 6-thioguanine nucleotides and 6methylmercaptopurine in whole-blood by LC/MSMS using isotope-labeled internal standards, Ther. Drug Monit., 35 (3), 313-321.

[9] Hawwa, A.F., Millership, J.S., Collier, P.S., and McElnay, J.C., 2009, Development and validation of an HPLC method for the rapid and simultaneous determination of 6-mercaptopurine and four of its metabolites in plasma and red blood cells, J. Pharm. Biomed. Anal., 49 (2), 401-409.

[10] Adaway, J.E., and Keevil, B.G., 2012, Therapeutic drug monitoring and LC-MS/MS, J. Chromatogr. B., 883-884, 33-49.

[11] Déglon, J., Thomas, A., Mangin, P., and Staub, C., 2012, Direct analysis of dried blood spots coupled with mass spectrometry: Concepts and biomedical applications, Anal. Bioanal. Chem., 402 (8), 24852498.

[12] De Kesel, P.M., Sadones, N., Capiau, S., Lambert, W.E., and Stove, C.P., 2013, Hemato-critical issues in quantitative analysis of dried blood spots: Challenges and solutions, Bioanalysis, 5 (16), 2023-2041.

[13] Sharma, A., Jaiswal, S., Shukla, M., and Lal, J., 2014, Dried blood spots: Concepts, present status, and future perspectives in bioanalysis, Drug Test. Anal., 6 (5), 399-414.

[14] Wilhelm, A.J., den Burger, J.C., and Swart, E.L., 2014, Therapeutic drug monitoring by dried blood spot: Progress to date and future directions, Clin. Pharmacokinet., 53 (11), 961-973.

[15] European Medicines Agency (EMEA), 2011, Committee for Medicinal Products for Human Use (CHMP): Guideline on Bioanalytical Method Validation, European Medicines Agency, London. 
[16] Jager, N.G., Rosing, H., Schellens, J.H., and Beijnen, J.H., 2014, Procedures and practices for the validation of bioanalytical methods using dried blood spots: A review, Bioanalysis, 6 (18), 24812514.

[17] Kang, J.S., 2012, "Principles and Applications of LC-MS/MS for the Quantitative Bioanalysis of Analytes in Various Biological Samples" in Tandem Mass Spectrometry - Applications and Principles, Prasain, J., (Ed.), InTech, 441-492.

[18] Leung, K.S., and Fong, B.M., 2014, LC-MS/MS in the routine clinical laboratory: Has its time come, Anal. Bioanal. Chem., 406 (9-10), 2289-2301.

[19] Chambers, A.G., Percy, A.J., Yang, J., Camenzind, A.G., and Borchers, C.H., 2013, Multiplexed quantitation of endogenous proteins in dried blood spots by multiple reaction monitoring-mass spectrometry, Mol. Cell. Proteomics, 12 (3), 781791.

[20] Matuszewski, B.K., Constanzer, M.L., and Chavez-Eng, C.M., 2003, Strategies for the assessment of matrix effect in quantitative bioanalytical methods based on HPLC-MS/MS, Anal. Chem., 75 (13), 3019-3030.

[21] Li, W., and Tse, F.L., 2010, Dried blood spot sampling in combination with LC-MS/MS for quantitative analysis of small molecules, Biomed. Chromatogr., 24 (1), 49-65. 